\title{
DAYA SAING DAN VARIABEL-VARIABEL YANG MEMENGARUHI NILAI EKSPOR BAN KARET INDONESIA KE SEPULUH NEGARA IMPORTIR TERBESAR DI DUNIA TAHUN 2001-2018
}

(COMPETITIVENESS AND VARIABLES AFFECTING THE EPORT VALUE OF INDONESIAN RUBBER TYRE TO TEN LARGEST IMPORTING CONTRIES IN THE WORLD, 2001-2018)

\section{Davin Giovanni Batara Francisco Nainggolan¹, Budyanra²}

1,2Politeknik Statistika STIS

Jl. Batu Giok VIII No. 181 RT 005/037, Bojong Rawalumbu, Rawalumbu, Kota Bekasi, Jawa Barat E-mail: 16.9065@stis.ac.id

\begin{abstract}
ABSTRAK
Indonesia adalah produsen karet alam terbesar kedua di dunia, namun Indonesia hanya bisa mengekspor karet alam tanpa mengolahnya lebih lanjut. Menurunnya harga karet alam di dunia sejak 2011 juga menekan kinerja ekspor karet alam Indonesia. Untuk mengatasi hal tersebut, Indonesia perlu mengekspor barang olahan dari karet, yaitu ban karet berkode HS 4011. Hal ini karena tingginya permintaan impor ban karet dari seluruh dunia dan ban karet Indonesia belum banyak diekspor ke negara-negara importir ban karet terbesar di dunia yang menjadi pasar terbesar ban karet di dunia. Maka, penelitian ini bertujuan untuk melihat daya saing ban karet Indonesia dan variabel-variabel yang mempengaruhi nilai ekspor ban karet Indonesia ke sepuluh negara importir terbesar ban karet di dunia tahun 2001-2018. Variabel-variabel yang digunakan ialah PDB riil perkapita negara tujuan, harga ekspor di negara tujuan, jumlah penduduk negara tujuan dan nilai tukar nominal Dolar AS terhadap Rupiah. Metode yang akan digunakan adalah Revealed Symmetrical Comparative Advantage (RSCA) dan analisis data panel. Hasil penelitian ini adalah ban karet Indonesia memiliki keunggulan komparatif di sepuluh negara importir ban karet terbesar di dunia. Hasil lainnya ialah PDB riil perkapita dan jumlah penduduk negara tujuan berpengaruh positif terhadap nilai ekspor ban karet Indonesia, sedangkan harga ekspor di negara tujuan dan nilai tukar nominal Dolar AS terhadap Rupiah berpengaruh negatif terhadap nilai ekspor ban karet Indonesia.
\end{abstract}

Kata kunci: karet alam, ban karet, revealed symmetrical comparative advantage, regresi data panel.

\section{ABSTRACT}

Indonesia is the second largest natural rubber producer in the world, but Indonesia can only export natural rubber without further processing it. The declining of natural rubber price in the world since 2011 also suppressed the Indonesia's natural rubber exports performance. To overcome this, Indonesia needs to export processed goods from rubber, namely HS 4011 coded rubber tires. This is due to the high demand for imported rubber tires from all over the world and Indonesia's rubber tires have not been widely exported to the world's largest rubber tire importer countries as the biggest rubber tire market in the world. Therefore, this study aims to look at the competitiveness of Indonesian rubber tires and the variables that affect the Indonesia's rubber tire export values to the ten largest rubber tire importing countries in the world in 2001-2018. The variables used are the real GDP per capita of the destination country, export prices in the destination country, the population of the destination country and the nominal exchange rate (Rp/USD). The method to be used is Revealed Symmetrical Comparative Advantage (RSCA) and panel data analysis. The results of this study is Indonesian rubber tires have a comparative advantage in the ten largest rubber tire importer countries in the world. Another results are that the real GDP per capita and the population of the destination country have a positive effect on the Indonesian rubber tire export values, while the export prices in the destination country and the nominal exchange rate have a negative effect on the Indonesia's rubber tire exports values.

Keywords: natural rubber, rubber tyre, revealed symmetrical comparative advantages, panel data regression. 


\section{PENDAHULUAN}

Indonesia merupakan salah satu negara penghasil karet alam terbesar di dunia. Menurut FAO, Indonesia telah menghasilkan 3,63 juta ton karet alam yang menjadikan Indonesia sebagai penghasil karet alam terbesar kedua di dunia pada 2017. Kemudian, Thailand sebagai penghasil karet alam terbesar pertama di dunia telah memproduksi 4,6 juta ton karet alam dan Vietnam diperingkat ketiga telah memproduksi 1,09 juta ton pada tahun yang sama.

Sebagian besar hasil karet alam Indonesia ditujukan untuk ekspor ke mancanegara. Menurut Gapkindo, sekitar 89 persen (3,27 juta ton) dari total produksi karet alam pada tahun 2017 telah diekspor ke mancanegara. Selain itu, sebagian besar karet alam Indonesia diekspor dalam bentuk karet remah, yaitu sebanyak 89,4 persen (2,92 juta ton) karet alam Indonesia diekspor dalam bentuk karet remah pada tahun tersebut. Ekspor karet remah berkontribusi besar pada nilai ekspor industri karet, barang dari karet dan plastik Indonesia. Menurut publikasi BPS, industri karet, barang dari karet dan plastik telah menyumbang sebesar USD 8,61 miliar terhadap ekspor Indonesia pada tahun 2017 yang mayoritas berasal dari nilai ekspor karet remah, yaitu sebesar 57,58 persen (USD 4,96 miliar) dari total ekspor industri tersebut.

Namun, sejak 2011 telah terjadi penurunan harga karet alam di dunia. Berdasarkan data harga karet bulanan pada SICOM (Singapore Commodity Exchange) periode 2011-2018, telah terjadi penurunan harga dari sekitar USD 6 per kilogram pada awal 2011 menjadi hanya sekitar USD 1,5 per kilogram pada akhir 2018. Hal ini tentu berpengaruh terhadap kinerja ekspor karet Indonesia yang banyak bertumpu pada komoditi karet alam.

Oleh karena itu, Indonesia perlu mengambil langkah lain untuk memaksimalkan potensi karet Indonesia. Salah satu langkah tersebut ialah mengekspor produk turunan karet, yaitu produk ban (kode HS 4011) yang permintaannya cukup tinggi dari seluruh dunia. Terdapat total sekitar USD 78,3 miliar nilai impor ban dari seluruh dunia. Nilai ini bahkan lebih besar bila dibandingkan total nilai impor karet alam dari seluruh dunia yang hanya USD 14,05 miliar pada tahun yang sama. Selain itu, Indonesia juga masih kalah dalam ekspor ban karet dibandingkan Thailand sebagai sesama produsen karet alam terbesar di dunia. Thailand telah mengekspor ban karet dengan nilai USD 4,94 miliar pada 2018 yang menjadikan Thailand sebagai eksportir ban karet terbesar kelima di dunia, sementara Indonesia hanya mengekspor ban karet dengan nilai USD 1,61 miliar.

Pada 2018, terdapat sepuluh negara tujuan utama ekspor ban Indonesia. Negara tersebut ialah Amerika Serikat, Jepang, Filipina, Malaysia, Australia. Jerman, Arab Saudi, Inggris, Thailand dan Brazil. Nilai ekspor ban Indonesia ke sepuluh negara tersebut pada 2018 sebesar USD 1,17 miliar atau mencapai 72,9 persen dari total keseluruhan ekspor ban Indonesia. Namun, dari sepuluh negara tersebut, hanya Amerika Serikat, Jerman, Australia. dan Inggris yang termasuk dalam sepuluh negara pengimpor ban terbesar dunia. Padahal, permintaan impor ban dari sepuluh negara pengimpor ban terbesar di dunia cukup mendominasi, yaitu sekitar 56,9 persen (USD 45,1 miliar) dari total impor ban dari seluruh dunia pada 2018. Tidak hanya itu, proporsi ban yang diimpor dari Indonesia ke sepuluh negara importir ban terbesar dunia juga tergolong kecil, yaitu hanya USD 1,02 miliar atau 2,3 persen saja dari total nilai ban yang diimpor oleh sepuluh negara importir ban karet di dunia.

Berdasarkan permasalahan-permasalahan tadi, penelitian ini bertujuan untuk menggambarkan ekspor ban Indonesia ke sepuluh negara importir ban terbesar, yaitu Amerika Serikat, Jerman, Prancis, Meksiko, Kanada, Inggris, Belanda, Italia, Australia, dan Belgia dan menggambarkan daya saing ban Indonesia di negara-negara importir terbesar tersebut dibandingkan negara-negara pesaing serta mengetahui variabel-variabel yang berpengaruh terhadap ekspor ban Indonesia ke negara-negara tersebut.

Penelitian terkait pernah dilakukan oleh beberapa peneliti. Penelitian yang dilakukan oleh Anshari, Khilla dan Permata (2017) menemukan bahwa secara simultan inflasi dan kurs berpengaruh terhadap nilai ekspor di negara ASEAN-5 (Indonesia, Malaysia, Filipina, Singapura 
dan Thailand), namun inflasi secara parsial hanya berpengaruh signifikan di Filipina saja. Anindhita (2012) menemukan bahwa permintaan ekspor industri manufaktur rentan akan resesi di negaranegara tujuan utamanya serta juga tidak mampu mengambil keuntungan dari depresiasi nilai tukar akibat kurangnya daya saing pada barang-barang ekspor industri manufaktur. Muharami dan Novianti (2018) yang menganalisa kinerja ekspor komoditi karet Indonesia ke Amerika Latin tahun 2007-2015 menemukan bahwa karet alam Indonesia mampu berkompetisi di pasar Amerika Latin. Kemudian, ditemukan pula bahwa faktor yang mempengaruhi ekspor karet alam Indonesia ke Amerika Latin adalah PDB negara tujuan, nilai tukar riil, harga ekspor dan jarak ekonomi. Penelitian mengenai ban karet sendiri pernah dilakukan oleh Wardani dan Mulatsih (2016). Penelitian ini menemukan bahwa ban Indonesia berdaya saing kuat di kawasan Amerika Latin, kecuali Argentina. Selain itu, ditemukan pula bahwa PDB riil perkapita negara tujuan, PDB perkapita Indonesia, jarak ekonomi, nilai tukar riil dan populasi berpengaruh signifikan terhadap ekspor ban Indonesia.

\section{METODE}

Ban didefinisikan oleh Indonesian Trade Promotion Center (ITPC) sebagai salah satu bagian penting dari kendaraan darat yang menutupi pelek suatu roda dan bersentuhan langsung dengan permukaan jalan. Ban karet tersusun oleh sejumlah bahan, dengan bahan penyusun utamanya adalah campuran karet alam dan sintesis dengan komposisi sekitar 45-47 persen pada suatu ban karet (The Composition of a Tyre: Typical Components, 2006). Komposisi karet alam pada campuran karet tersebut berada pada kisaran 35-55 persen dari total campuran karet, bahkan bisa mencapai sekitar 80-100 persen pada kendaraan off the road (giant/earthmower) dan pesawat terbang (Balittri, 2013). Ban karet sendiri tergolong kedalam kode HS 4011 dan 4012, yaitu ban pneumatic baru dan bekas. Diantara keduanya, ban karet dengan kode HS 4011 menjadi produk yang terbanyak di ekspor Indonesia ke mancanegara. Selain penggolongan pada kode HS, ban karet juga dapat digolongkan kedalam klasifikasi lain seperti Klasifikasi Baku Lapangan Usaha Indonesia (KBLI) dan Klasifikasi Baku Komoditi Indonesia (KBKI). Pada KBLI, ban karet dengan kode HS 4011 digolongkan kedalam industri pengolahan dengan kategori/kode 2211. Sementara, ban karet dengan kode HS 4011 pada KBKI digolongkan pada kelas 3611 dengan rincian subkelas 36111, 36112 dan 36113.

Daya saing menurut Organisation for Economic Cooperation and Develompent (OECD) ialah kemampuan suatu negara dalam memproduksi barang maupun jasa dengan skala internasional melalui perdagangan yang bebas dan adil serta menjaga dan meningkatkan pendapatan riil masyarakat untuk jangka panjang. Terdapat dua faktor yang menentukan daya saing, yaitu faktor keunggulan komparatif yang bersifat alamiah dan faktor keunggulan kompetitif yang bersifat dapat dikembangkan (Tambunan, 2004). Salah satu metode mengukur daya saing ialah Revealed Comparative Advantage (RCA) oleh Bale Balassa pada tahun 1965 yang membandingkan peranan suatu komoditi pada ekspor total suatu negara dengan pangsa komoditi tersebut dalam perdagangan seluruh dunia. Nilai RCA akan berada pada rentang nol hingga tak berhingga yang menyebabkan masalah asymmetrical sehingga memberi pembobotan yang berbeda saat dilakukan analisis regresi (Laursen, 2015). Oleh karena itu, Laursen mengembangkan metode Revealed Symmetric Comparative Advantage (RSCA) pada 1998 yang menyesuaikan nilai RCA kedalam bentuk simetris disekitar nilai netralnya. Untuk menghitung RSCA digunakan rumus sebagai berikut (Saleh dan Widodo, 2010):

$$
\begin{aligned}
& R S C A_{i j}=\frac{R C A_{i j}-1}{R C A_{i j}+1} . \\
& R C A_{i j}=\frac{X_{i j} / X_{i}}{W_{j} / W} \ldots . .
\end{aligned}
$$


Keterangan:

Xij : nilai ekspor negara-i pada komoditi-j

$\mathrm{Xi}$ : nilai ekspor total negara-I

Wj: nilai ekspor dunia (selain negara-i) pada komoditi-j

W : nilai ekspor total dunia (selain negara-i)

Data yang digunakan pada penelitian ini merupakan data sekunder dari sepuluh negara importir ban karet terbesar di dunia yang bersumber dari UN Comtrade dan World Bank. Kesepuluh negara tersebut adalah Amerika Serikat, Jerman, Prancis, Meksiko, Kanada, Inggris, Belanda, Italia, Australia dan Belgia. Untuk ban karet yang digunakan adalah komoditi yang termasuk kedalam kode HS 4011 (ban pneumatic baru). Variabel-variabel yang digunakan dalam penelitian ini adalah nilai ekspor ban karet Indonesia ke negara tujuan, Pendapatan Domestik Bruto (PDB) riil perkapita negara tujuan, harga ekspor ban karet di negara tujuan, jumlah penduduk negara tujuan dan nilai tukar nominal Dolar Amerika Serikat terhadap Rupiah.

Analisis yang digunakan dalam penelitian ini berupa analisis deskriptif dan analisis inferensia. Analisis deskriptif berupa grafik digunakan untuk menggambarkan ekspor ban karet Indonesia ke sepuluh negara importir ban karet terbesar di dunia dari tahun ke tahun. Lalu, Revealed Symmetric Comparative Advantage (RSCA) digunakan untuk menggambarkan daya saing ban karet Indonesia di sepuluh negara importir terbesar ban karet di dunia. Selain melihat daya saing Indonesia sendiri, penelitian ini juga akan membandingkan daya saing Indonesia dengan negaranegara pesaing Indonesia, yaitu lima negara eksportir ban karet terbesar di dunia. Negara-negara tersebut adalah Amerika Serikat, Tiongkok, Jerman, Jepang dan Thailand.

Analisis inferensia berupa data panel digunakan untuk mengetahui variabel-variabel yang mem mempengaruhi nilai ekspor ban karet Indonesia ke sepuluh negara importir ban karet terbesar di dunia. Persamaan umum model data panel yang digunakan adalah sebagai berikut:

$$
N_{L I L I}=\alpha+\beta_{1} P D B r i i l_{i t}+\beta_{2} P R I C E_{i t}+\beta_{3} P O P_{i t}+\beta_{4} E R_{i t}+\varepsilon_{i t}
$$

Keterangan:

$\begin{array}{ll}\alpha & =\text { intersep } \\ \beta_{k} & =\text { koefisien regresi variabel independen ke-k, dengan } \mathrm{k}=1, \ldots, 4 \\ \varepsilon_{i t} & =\text { error term } \\ \text { NILAI } & =\text { nilai ekspor ban karet Indonesia ke negara ke-i dan tahun ke-t } \\ P D B r i i l_{i t} & =\text { PDB riil perkapita negara ke-i dan tahun ke-t } \\ P R I C E_{i t} & =\text { harga ekspor ban karet Indonesia ke negara ke-i dan tahun ke-t } \\ P O P_{i t} & =\text { jumlah penduduk negara ke-i dan tahun ke-t } \\ E R_{i t} & =\text { nilai tukar Dolar Amerika Serikat terhadap Rupiah di negara ke-i dan tahun ke-t }\end{array}$

\section{HASIL DAN PEMBAHASAN}

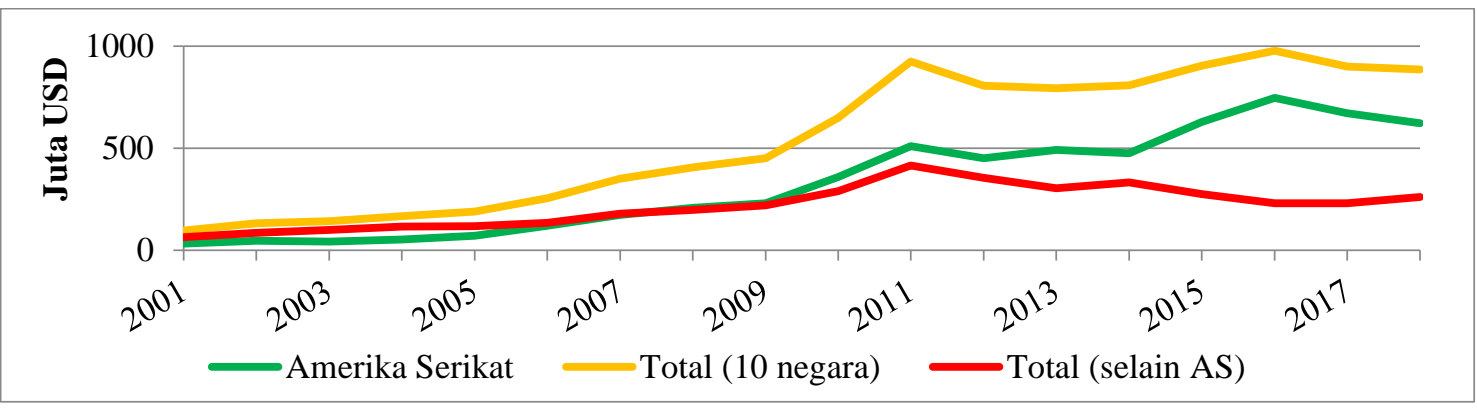

Sumber: UN Comtrade (diolah)

Gambar 1. Nilai ekspor ban karet Indonesia ke sepuluh negara importir terbesar 2001-2018

Gambar 1 menunjukkan total ekspor ban karet Indonesia ke sepuluh negara importir terbesar di dunia secara umum meningkat dari tahun ke tahun. Namun, pada 2011 hingga 2018 terjadi fluktuasi dengan rentang nilai ekspor sekitar 800 juta hingga 1 miliar USD. Terlihat pula nilai 
ekspor ke AS cenderung mendominasi, bahkan mencapai sekitar 622 juta USD dari total sekitar 884 juta USD pada 2018. Besarnya dominasi ini bahkan mampu menjaga total nilai ekspor ban karet Indonesia di kisaran 800 juta hingga 1 miliar USD pada 2011-2018, padahal pada periode tersebut nilai ekspor ke sembilan negara selain AS cenderung turun dari sekitar 415 juta USD pada 2011 menjadi sekitar 261 juta USD pada 2018.

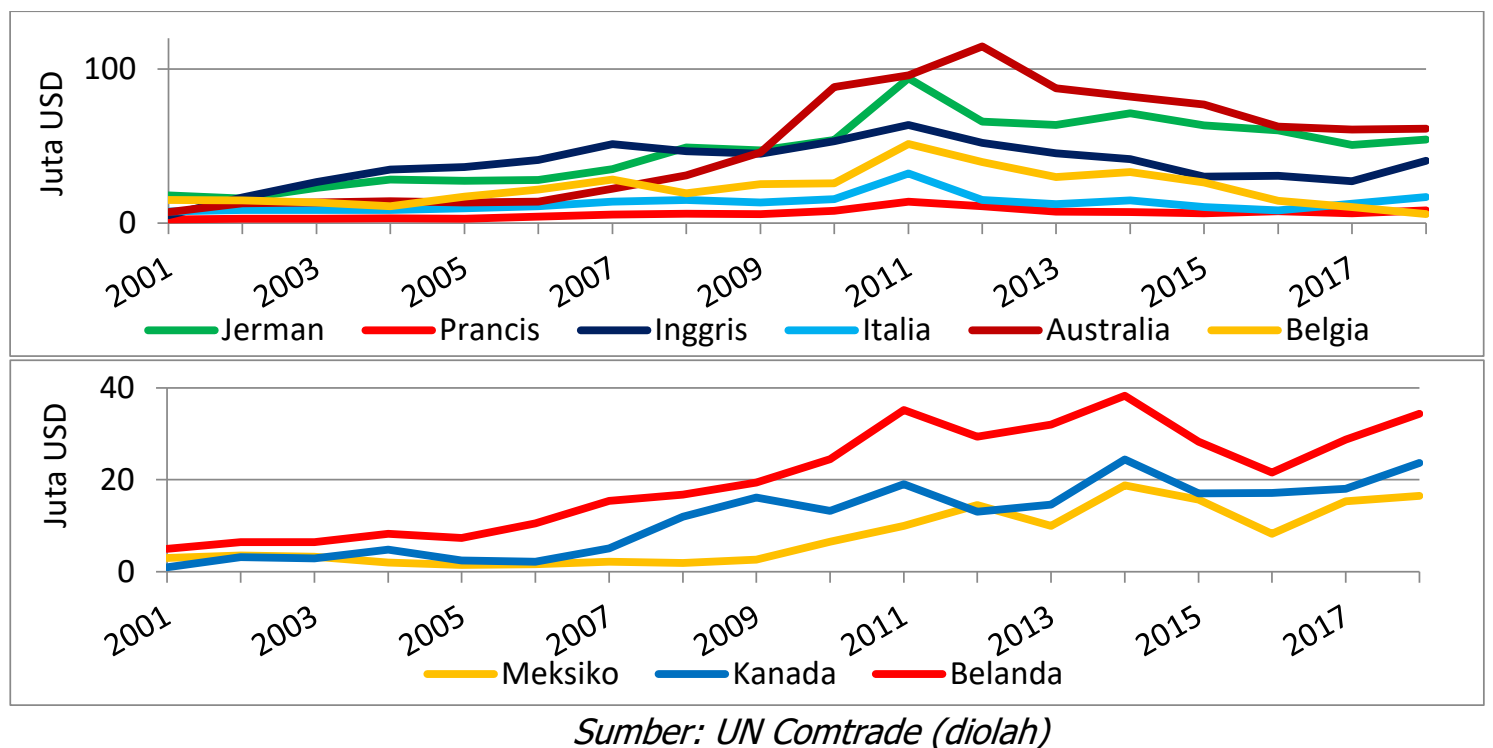

Gambar 2. Nilai ekspor ban karet Indonesia ke sembilan negara importir terbesar selain AS 2001-2018

Dari Gambar 2 terlihat bahwa ada dua tren nilai ekspor yang dialami oleh sembilan negara importir terbesar selain AS tahun 2001-2018. Pertama, terdapat tren peningkatan nilai ekspor pada 2001-2011 kemudian turun hingga 2018 yang terjadi pada nilai ekspor ke Jerman, Prancis, Inggris, Italia, Australia dan Belgia. Kedua ialah tren peningkatan nilai ekspor pada 2001-2011 kemudian cenderung konstan dengan sedikit fluktuasi, bahkan meningkat hingga 2018 yang terjadi pada nilai ekspor ke Meksiko, Kanada dan Belanda.

\section{GAMBARAN UMUM DAYA SAING BAN KARET INDONESIA}

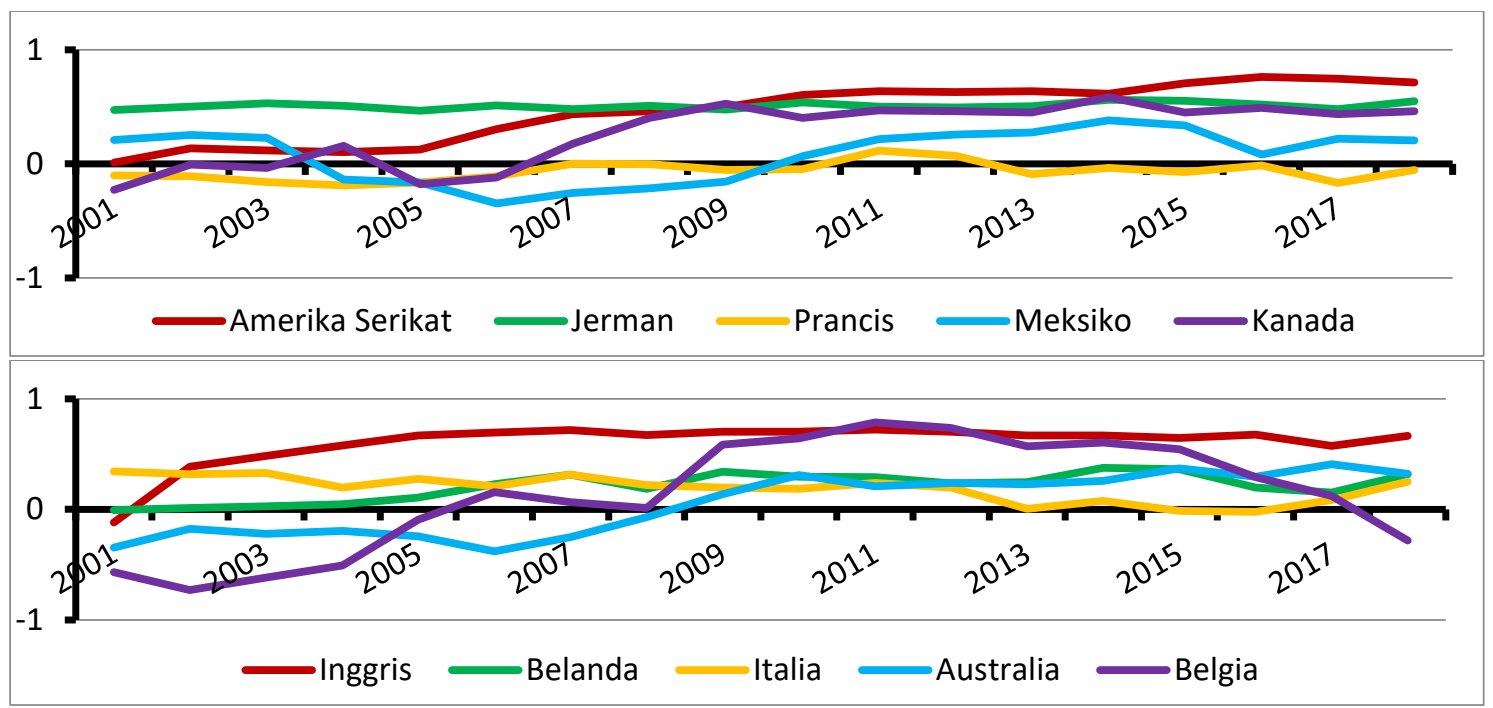

Sumber: UN Comtrade (diolah)

Gambar 3. Nilai RSCA ban karet Indonesia di sepuluh negara importir ban karet terbesar di dunia 2001-2018

Dari Gambar 3 terlihat bahwa secara umum, nilai RSCA ban karet Indonesia cenderung selalu bernilai positif, kecuali di Prancis yang cenderung selalu bernilai negatif. Hal ini menunjukkan bahwa secara umum, ban karet Indonesia telah memiliki keunggulan komparatif di sembilan negara importir ban karet terbesar di dunia selain Prancis. 
Jika dilihat lebih lanjut, nilai RSCA ban karet Indonesia di AS, Jerman, Inggris, Belanda dan Italia cenderung bernilai positif. Nilai RSCA Indonesia di AS dan Belanda cenderung meningkat dari tahun 2001-2018. Kemudian, nilai RSCA Indonesia di Jerman cenderung konstan dan stabil dari tahun 2001-2018. Lalu, nilai RSA Indonesia di Inggris meningkat pada 2001-2007 lalu konstan hingga 2018. Sementara, nilai RSCA Indonesia di Italia cenderung konstan hingga tahun 2011 lalu turun hingga bernilai negatif pada 2015-2016 kemudian kembali naik hingga 2018. Kemudian, nilai RSCA Indonesia di Kanada, Meksiko, Australia dan Belgia cenderung meningkat dari awalnya negatif hingga menjadi positif. Nilai RSCA Indonesia di Kanada dan Australia cenderung serupa dimana pada 2001bernilai negatif lalu terus meningkat hingga sekitar 2009-2010 lalu cenderung konstan hingga 2018. Selanjutnya, nilai RSCA Indonesia di Meksiko cenderung berfluktuasi, dimana pada 2004-2009 sempat turun hingga bernilai negatif. Sementara itu, nilai RSCA di Belgia mengalami peningkatan dari awalnya bernilai negatif pada 2001-2005 kemudian terus meningkat hingga mencapai nilai tertinggi 0,78 pada 2011 dan kemudian menurun hingga 2018.

\section{GAMBARAN UMUM DAYA SAING BAN KARET INDONESIA DIBANDINGKAN NEGARA PESAING}

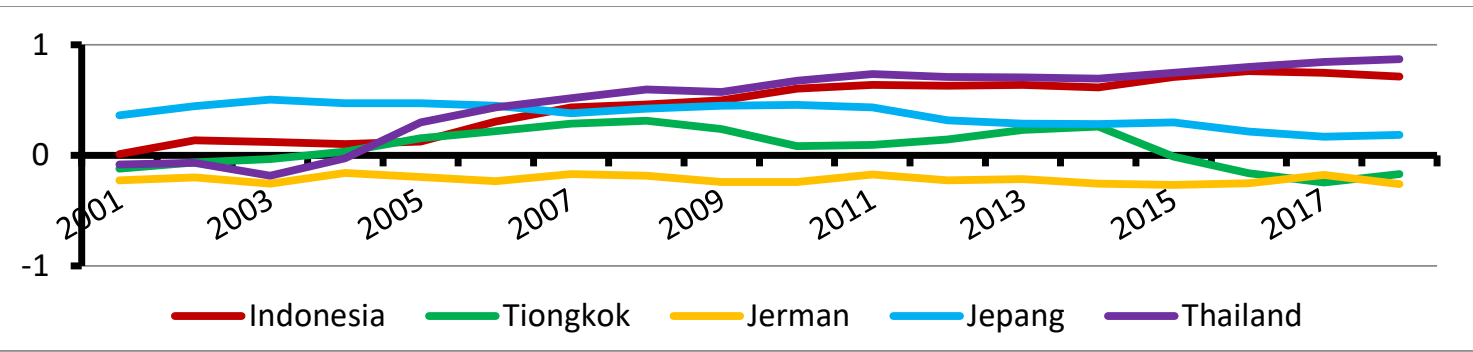

Sumber: UN Comtrade (diolah)

Gambar 4. Nilai RSCA ban karet Indonesia dan negara pesaing di Amerika Serikat 2001-2018

Secara umum, Indonesia, Tiongkok, Jepang dan Thailand memiliki keunggulan komparatif di Amerika Serikat selama 2001-2018. Sementara itu, Jerman cenderung tidak memiliki keunggulan komparatif di AS pada 2001-2018. Indonesia dan Thailand menunjukkan peningkatan nilai RSCA dari tahun ke tahun, bahkan Thailand mampu mengungguli nilai RSCA Indonesia sejak 2005 hingga 2018. Kemudian, Tiongkok menunjukkan fluktuasi nilai RSCA dan sempat bernilai negatif pada 2015-2018. Sementara itu, Jepang menunjukkan penurunan nilai RSCA namun tetap bernilai positif.

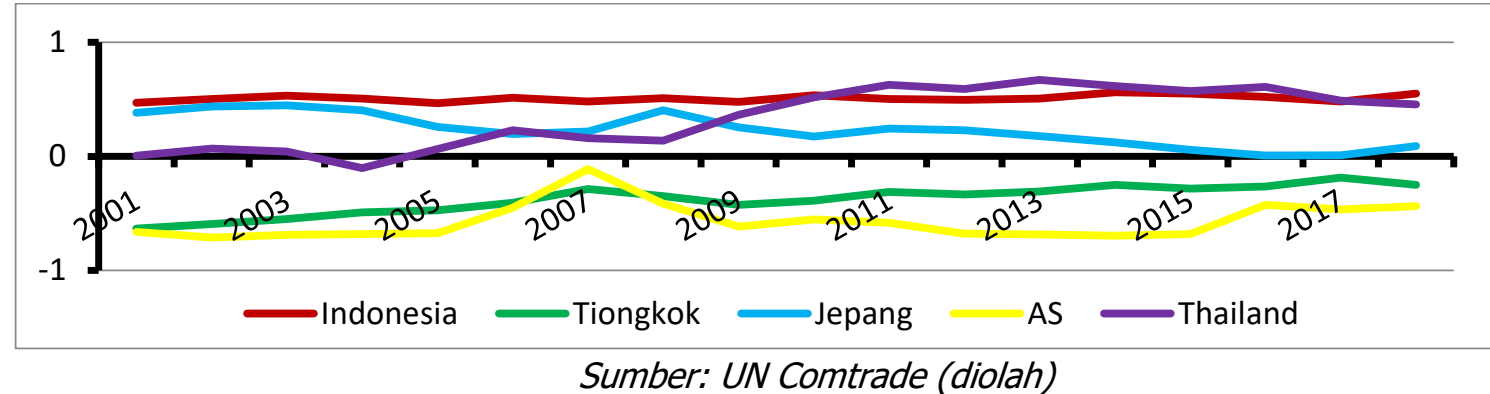

Gambar 5. Nilai RSCA ban karet Indonesia dan negara pesaing di Jerman 2001-2018

Secara umum, Indonesia, Jepang dan Thailand memilki keunggulan komparatif di Jerman selama 2001-2018. Sementara, Tiongkok dan AS cenderung tidak memiliki keunggulan komparatif di AS pada 2001-2018, walaupun Tiongkok menunjukkan peningkatan nilai RSCA. Indonesia memiliki nilai RSCA yang konstan selama 2001-2018. Kemudian, nilai RSCA Thailand cenderung meningkat, bahkan sempat menungguli RSCA Indonesia pada 2011-2017. Sementara itu, Jepang cenderung menunjukkan penurunan nilai RSCA walaupun sempat mengalami peningkatan pada 2008. 


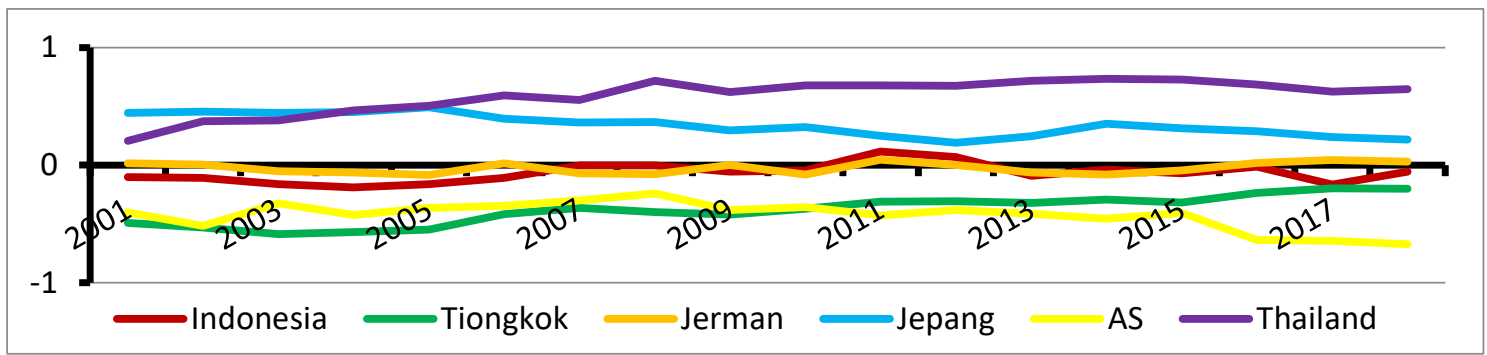

Sumber: UN Comtrade (diolah)

Gambar 6. Nilai RSCA ban karet Indonesia dan negara pesaing di Prancis 2001-2018

Secara umum, hanya Jepang dan Thailand yang memiliki keunggulan komparatif di Prancis selama 2001-2018. Sementara itu, Indonesia, Tiongkok, Jerman dan AS cenderung tidak memiliki keunggulan komparatif di Prancis pada 2001-2018. Jepang menunjukkan penurunan nilai RSCA selama 2001-2018. Kebalikan dengan hal tersebut, Thailand cenderung menunjukkan peningkatan nilai RSCA selama 2001-2018.

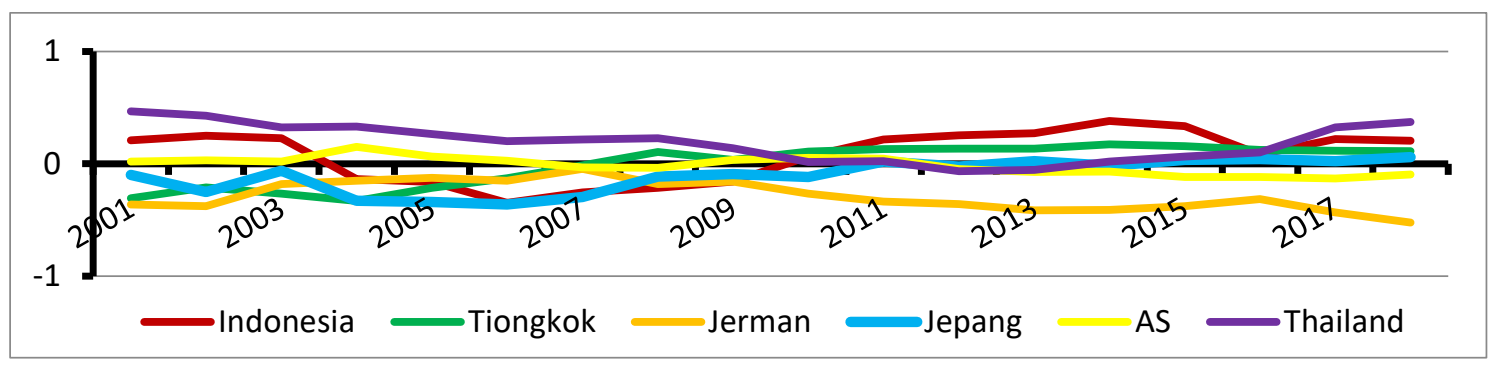

Sumber: UN Comtrade (diolah)

Gambar 7. Nilai RSCA ban karet Indonesia dan negara pesaing di Meksiko 2001-2018

Secara umum, Indonesia, Tiongkok dan Thailand cenderung memiliki keunggulan komparatif di Meksiko selama 2001-2018. Sementara itu, Jerman, Jepang dan AS cenderung tidak memiliki keunggulan komparatif di Meksiko pada 2001-2018. Indonesia menunjukkan fluktuasi nilai RSCA, bahkan sempat berada bernilai negatif pada 2004-2009. Kemudian, nilai RSCA Tiongkok meningkat dari bernilai negatif hingga 2007 lalu naik menjadi positif kemudian cenderung stabil pada 20102018. Nilai RSCA Thailand sendiri menurun hingga bernilai negatif pada 2012-2013 lalu kembali meningkat sampai 2018.

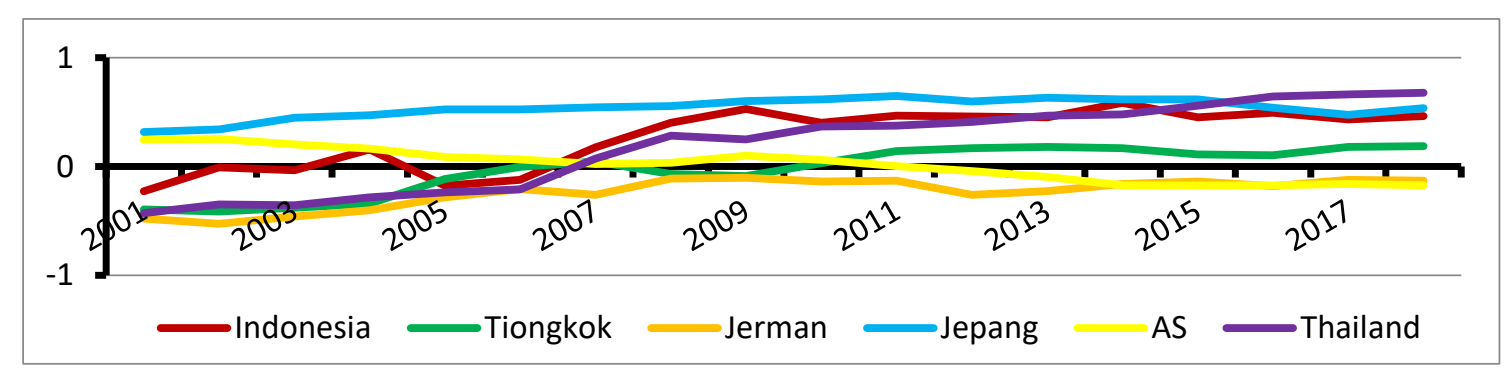

Sumber: UN Comtrade (diolah)

Gambar 8. Nilai RSCA ban karet Indonesia dan negara pesaing di Kanada 2001-2018

Secara umum, Indonesia, Jepang dan Thailand cenderung memiliki keunggulan komparatif di Kanada pada 2001-2018. Sementara itu, Jerman tidak memiliki keunggulan komparatif di Kanada pada 2001-2018. Tiongkok sendiri menunjukkan keunggulan komparatif pada 2010-2018 walaupun sebelumnya cenderung tidak memiliki keunggulan komparatif. Sebaliknya, AS justru tidak memiliki keunggulan komparatif pada 2011-2018 walaupun sebelumnya memiliki keunggulan komparatif. Nilai RSCA Indonesia dan Thailand cenderung meningkat, bahkan Indonesia sempat mengungguli Thailand pada 2016-2018. Sementara itu, nilai RSCA Jepang cenderung stabil pada 2001-2015. 


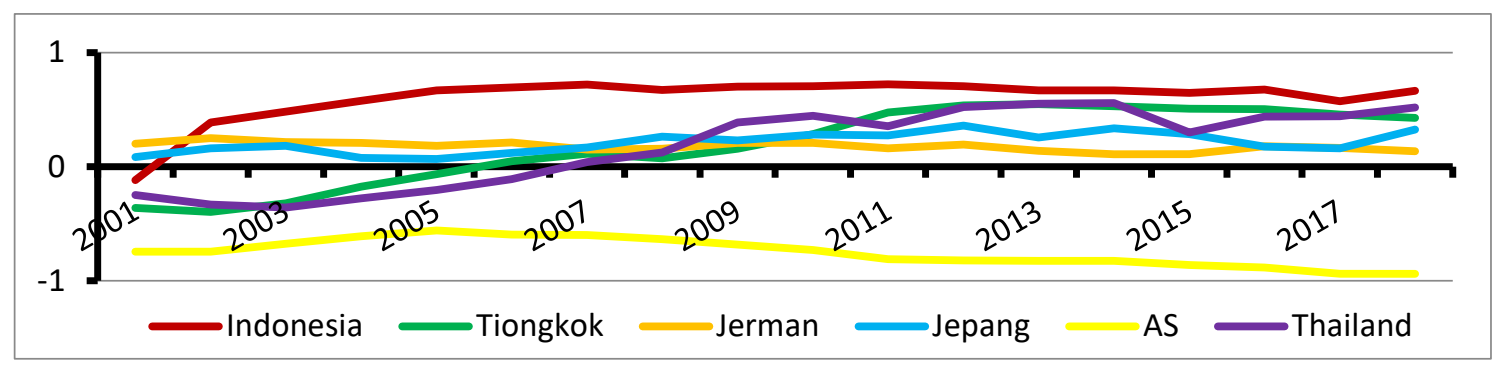

Sumber: UN Comtrade (diolah)

Gambar 9. Nilai RSCA ban karet Indonesia dan negara pesaing di Inggris 2001-2018

Secara umum, Indonesia, Tiongkok, Jerman, Jepang dan Thailand cenderung memiliki keunggulan komparatif di Inggris pada 2001-2018. Sementara itu, AS tidak memiliki keunggulan komparatif di Inggris pada 2001-2018. Nilai RSCA Indonesia meningkat cukup tinggi pada 20012005 kemudian cenderung konstan hingga 2018. Nilai RSCA Tiongkok dan Thailand memiliki kemiripan dimana sekitar 2001-2006 bernilai negatif kemudian meningkat menjadi positif dan konstan pada tahun 2012-2018. Sementara itu, nilai RSCA Jerman dan Jepang cenderung konstan walaupun untuk Jerman sendiri cenderung sedikit menurun dan Jepang cenderung sedikit meningkat.

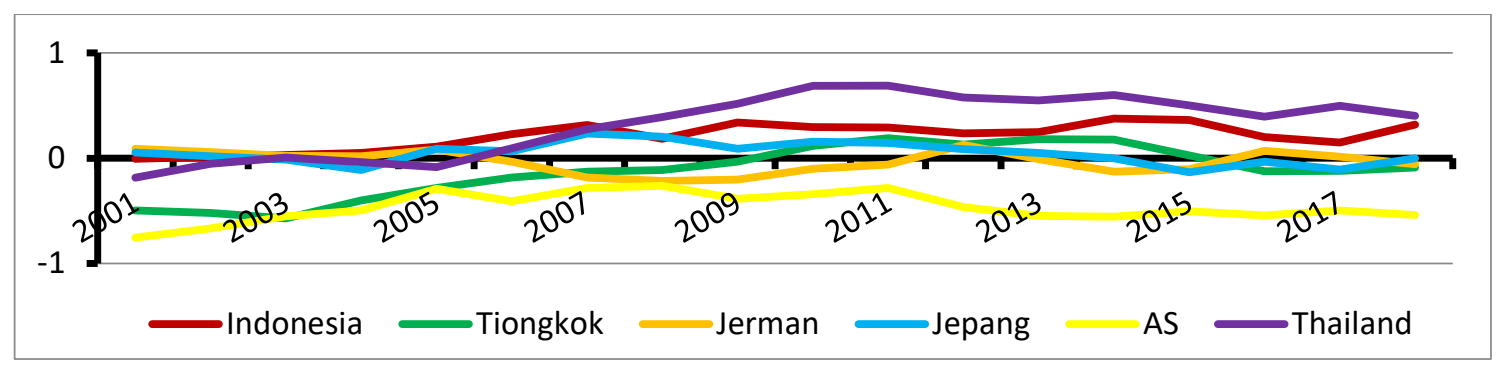

Sumber: UN Comtrade (diolah)

Gambar 10. Nilai RSCA ban karet Indonesia dan negara pesaing di Belanda 2001-2018

Secara umum, Indonesia, Jepang dan Thailand memiliki keunggulan komparatif di Belanda pada 2001-2018. Sementara itu, Tiongkok, Jerman dan AS cenderung tidak memiliki keunggulan komparatif di Belanda pada 2001-2018. Nilai RSCA Indonesia sendiri meningkat pada 2001-2007 kemudian cenderung konstan hingga 2018. Lalu, nilai RSCA Jepang meningkat pada 2001-2007 kemudian menurun hingga bernilai negatif pada 2015-2018. Sementara itu, Nilai RSCA Thailand meningkat pada 2001-2011 kemudian menurun hingga 2018.

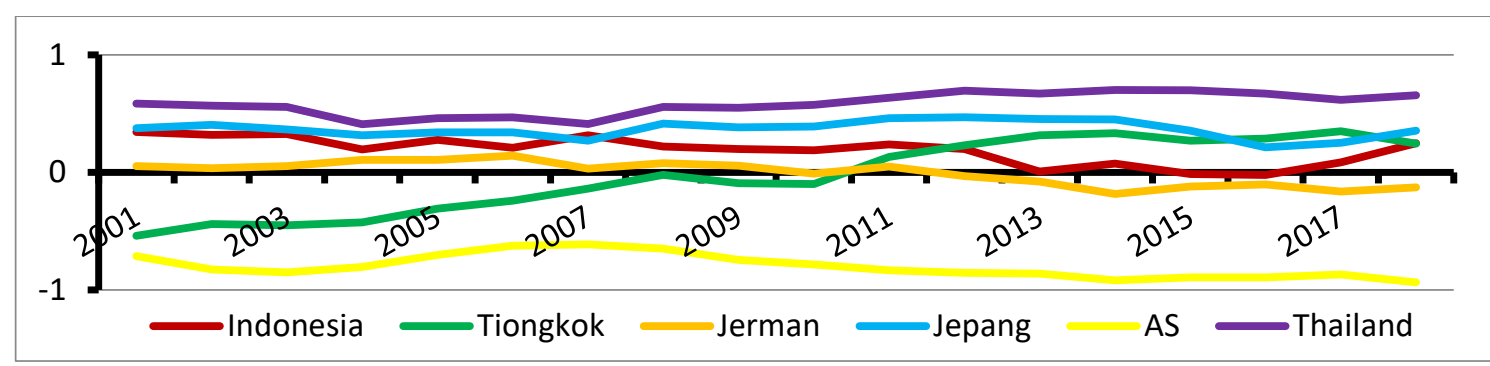

Sumber: UN Comtrade (diolah)

Gambar 11. Nilai RSCA ban karet Indonesia dan negara pesaing di Italia 2001-2018

Secara umum, Indonesia, Jepang dan Thailand memiliki keunggulan komparatif di Italia pada 2001-2018. Sementara itu, AS tidak memiliki keunggulan komparatif di Italia pada 2001-2018. Tiongkok sendiri hanya menunjukkan keunggulan komparatif pada 2011-2018 namun sebelumnya tidak menunjukkan keunggulan komparatif. Jerman sendiri justru tidak memiliki keunggulan komparatif pada 2012-2018 padahal sebelumnya cenderung menunjukkan daya saing. Nilai RSCA Indonesia cenderung menurun pada 2001-2016 kemudian meningkat hingga 2018. Nilai RSCA Jepang dan Thailand cenderung konstandengan sedikit fluktuasi. 


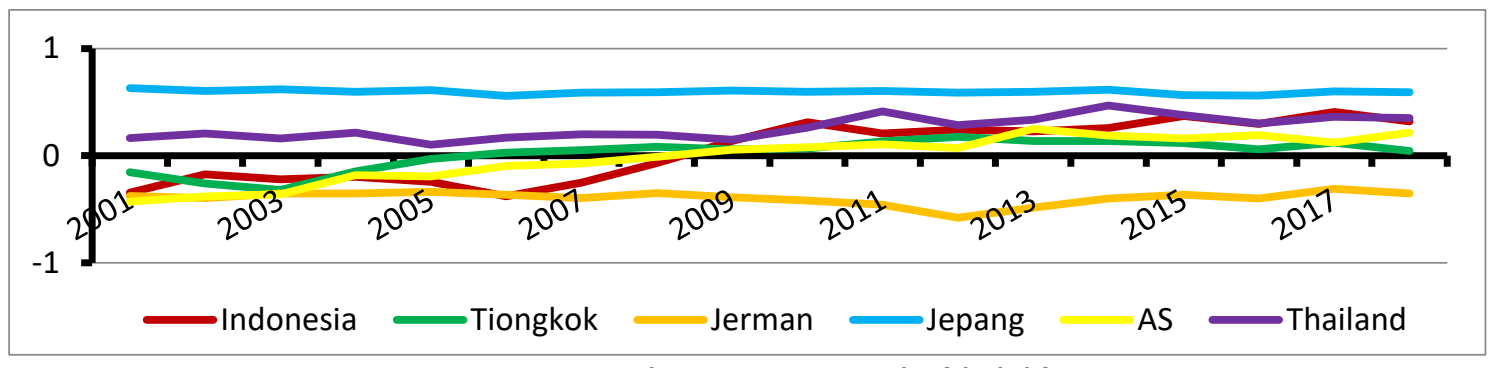

Sumber: UN Comtrade (diolah)

Gambar 11. Nilai RSCA ban karet Indonesia dan negara pesaing di Australia 2001-2018

Secara umum, Jepang, Tiongkok dan Thailand memiliki keunggulan komparatif di Australia pada 2001-2018. Sementara itu, Jerman tidak memiliki keunggulan komparatif di Asutralia pada 2001-2018. Indonesia dan AS sendiri tidak memiliki keunggulan komparatif pada 2001-2008 dan baru memiliki keunggulan komparatif di tahun-tahun berikutnya. Nilai RSCA Jepang sendiri cenderung konstan. Lalu, nilai RSCA Tiongkok meningkat dari bernilai negatif pada 2001-2006 kemudian positif pada tahun-tahun berikutnya. Sementara itu, nilai RSCA Thailand cenderung sedikit meningkat dari 2001-2018.

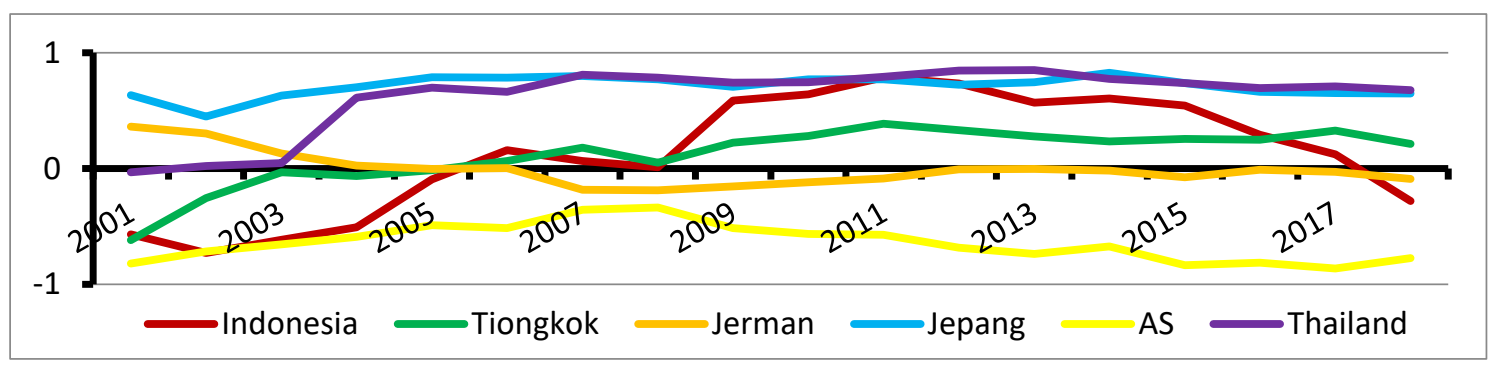

Sumber: UN Comtrade (diolah)

Gambar 12. Nilai RSCA ban karet Indonesia dan negara pesaing di Belgia 2001-2018

Secara umum, Indonesia, Tiongkok, Jepang dan Thailand memiliki keunggulan komparatif di Belgia pada 2001-2018. Sementara, Jerman dan AS cenderung tidak memiliki keunggulan komparatif di Belgia pada 2001-2018. Nilai RSCA Indonesia cenderung meningkat dari bernilai negatif pada 2001-2005 kemudian meningkat hingga 2011, lalu kembali menurun hingga 2018. Nilai RSCA Tiongkok sendiri cenderung meningkat, dari bernilai negatif pada 2001-2005 kemudian meningkat hingga 2018. Nilai RSCA Jepang sendiri cenderung konstan walaupun sempat berada di titik terendahnya, yaitu 0,44 pada 2002. Sementara itu, nilai RSCA Thailand cenderung meningkat pesat pada 2001-2007 kemudian cenderung konstan pada tahun-tahun berikutnya.

\section{VARIABEL-VARIABEL YANG MEMPENGARUHI NILAI EKSPOR BAN KARET INDONESIA}

Berdasarkan hasil pengolahan data, Uji Chow dan Hausmann menghasilkan p-value $(0,0000)$ yang lebih kecil daripada a $(0,05)$. Dengan hasil tersebut, model FEM terpilih dalam melakukan analisis regresi data panel serta dilakukan pengujian struktur matriks varians-kovarians. Pertama, dari pengujian LM didapatkan nilai $L M_{\text {hitung }}(89,0097)$ lebih besar daripada $X_{(0,05 ; 9)}^{2}(16,9190)$ yang menghasilkan keputusan tolak $\mathrm{HO}$. Oleh karena itu, pengujian dilanjutkan dengan uji $\lambda \mathrm{LM}$. Pada pengujian ini didapatkan nilai $\lambda_{L M}(239,8415)$ lebih besar daripada $X_{(0,05 ; 45)}^{2}(61,6562)$ yang menghasilkan keputusan tolak HO. Dengan begitu, melalui kedua uji ini disimpulkan terdapat heteroskedastisitas dan cross-section correlation serta estimasi FGLS akan diterapkan pada model terpilih FEM. Selanjutnya, akan dilakukan pengujian asumsi klasik.

Pengujian asumsi klasik yang dilakukan ialah uji asumsi normalitas dan nonmultikolinearitas. Pengujian asumsi normalitas dilakukan melalui uji Jarque Bera. Dari pengujian tersebut, didapatkan $p$-value $(0,6402)$ lebih besar daripada a $(0,05)$ yang menghasilkan keputusan gagal tolak $\mathrm{HO}$ atau dapat disimpulkan asumsi kenormalan terpenuhi. Kemudian, dilakukan pengujian nonmultikolinearitas dengan melihat nilai centered VIF dari setiap variabel independen. Melalui pengujian tersebut ditemui bahwa semua variabel independen memiliki nilai centered VIF yang 
lebih kecil dari 10. Dengan hal itu, dapat disimpulkan bahwa asumsi nonmultikolinearitas terpenuhi.

Dari pengolahan data, dapat dibentuk estimasi persamaan regresi data panel sebagai berikut:

$$
\begin{aligned}
& \widehat{N I L A} I_{i t}=\left(-1,06 \mathrm{E}+09+\lambda_{i}\right)+6565,8250 \text { PDBriil }_{i t}{ }^{*}-6630308 \text { PRICE }_{i t}{ }^{*}+12,6581 \text { POP }_{i t}{ }^{*}- \\
& 9780,8080 E R_{i t}^{*}
\end{aligned}
$$

Adjusted $R$-squared $=0,9592 ;$ Prob $($ F-statistic $)=0,0000$

*) signifikan pada a $(0,05)$

Dari model tersebut diketahui nilai Prob (F-statistic) sebesar 0,0000 lebih kecil daripada a $(0,05)$. Dapat disimpulkan bahwa terdapat minimal satu variabel independen yang berpengaruh signifikan terhadap variabel dependen. Kemudian, secara parsial ditemukan bahwa dalam taraf signifikansi 0,05 semua variabel bebas berpengaruh signifikan terhadap nilai ekspor ban karet Indonesia. Dengan kata lain, variabel-variabel independen yang digunakan (PDBriil, Price, POP, ER) secara parsial berpengaruh signifikan terhadap variabel dependen. Selanjutnya, diketahui pula nilai Adjusted R-squared sebesar 0,9592 yang menunjukkan bahwa variabel-variabel independen yang digunakan pada model mampu menjelaskan variasi dari perubahan nilai ekspor ban karet Indonesia ke sepuluh negara importir terbesar di dunia sebesar sekitar 95 persen, sementara 5 persen lainnya dijelaskan oleh variabel lain yang tidak tercakup pada model.

Berdasarkan hasil estimasi, terdapat hasil efek individu. Efek individu akan menyebabkan perbedaan pada nilai intersep ketika semua variabel bebas bernilai sama. Pada Tabel 1 menunjukkan bahwa Belgia memiliki efek individu tertinggi yaitu sebesar 7,87E+08 . Hal tersebut berarti ketika semua variabel bebas dianggap nol, maka rata-rata ekspor kakao olahan Indonesia ke Belgia sebesar USD 787 juta.

Tabel 32. Output cross-section fixed effect

No

(1)

1

2

3

4

5

6

7

8

9

10
Negara

(2)

Amerika Serikat

Jerman

Prancis

Meksiko

Kanada

Inggris

Belanda

Italia

Australia

Belgia
Efek Individu

(2)

$$
\begin{array}{r}
-2,69 \mathrm{E}+09 \\
-6,11 \mathrm{E}+07 \\
1,10 \mathrm{E}+08 \\
-3,01 \mathrm{E}+08 \\
4,67 \mathrm{E}+08 \\
1,71 \mathrm{E}+08 \\
6,73 \mathrm{E}+08 \\
2,20 \mathrm{E}+08 \\
6,25 \mathrm{E}+08 \\
7,87 \mathrm{E}+08
\end{array}
$$

Variabel PDB riil perkapita negara tujuan berpengaruh positif signifikan terhadap nilai ekspor ban karet Indonesia ke sepuluh negara importir terbesar di dunia. Setiap kenaikan PDB riil perkapita negara tujuan sebesar 100 USD akan meningkatkan nilai ekspor ban karet Indonesia ke negara tersebut sebesar sekitar 656 ribu USD. Hal ini sesuai dengan pernyataan Sukirno (2005) bahwa peningkatan pendapatan pembeli yang tercermin dari PDB riil perkapita negara tujuan akan meningkatan permintaan terhadap satu komoditi.

Variabel harga ekspor ban karet Indonesia di negara tujuan berpengaruh negatif signifikan terhadap nilai ekspor ban karet ke sepuluh negara importir terbesar di dunia. Setiap kenaikan harga ekspor ban karet Indonesia di negara tujuan sebesar 0,1 USD/kg akan menurunkan nilai ekspor ban karet Indonesia ke negara tersebut sebesar sekitar 663 ribu USD. Hal ini sesuai dengan pernyataan Sukirno (2005) bahwa peningkatan harga suatu komoditi akan menurunkan permintaan terhadap komoditi tersebut. 
Variabel jumlah penduduk negara tujuan berpengaruh positif signifikan terhadap nilai ekspor ban karet ke sepuluh negara importir terbesar di dunia. Setiap kenaikan jumlah penduduk negara tujuan sebesar 1 juta jiwa akan meningkatkan nilai ekspor ban karet Indonesia ke negara tersebut sebesar sekitar 12,65 juta USD. Hal ini sejalan dengan penelitian yang dilakukan oleh Wardani dan Mulatsih yang menemukan bahwa jumlah penduduk (populasi) negara tujuan berpengaruh positif signifikan terhadap ekspor ban Indonesia.

Variabel nilai tukar Dolar AS terhadap Rupiah berpengaruh negatif signifikan terhadap nilai ekspor ban karet ke sepuluh negara importir terbesar di dunia. Setiap kenaikan nilai tukar Dolar AS terhadap Rupiah (depresiasi Rupiah) sebesar 100 Rupiah/USD akan menurunkan nilai ekspor ban karet Indonesia ke negara tersebut sebesar sekitar 978 ribu USD. Hal ini sejalan dengan penelitian Anshari, Khilla dan Permata (2017) yang menemukan bahwa depresiasi nilai tukar Rupiah berpengaruh negatif signifikan terhadap ekspor Indonesia. Hal ini dijelaskan oleh hasil penelitian Anindhita (2012) yang menemukan bahwa ekspor industri manufaktur (termasuk ban karet) tidak mampu mengambil keuntungan dari depresiasi nilai tukar Rupiah, sehingga ekspor industri manufaktur Indonesia justru mengalami penurunan akibat depresiasi nilai tukar Rupiah.

\section{KESIMPULAN}

Berdasarkan hasil tersebut, dapat disimpulkan beberapa hal. Pertama, nilai ekspor ban karet Indonesia ke sepuluh negara importir ban karet terbesar di dunia pada 2001-2018 mengalami peningkatan dengan masih didominasi oleh tujuan ekspor ke Amerika Serikat.

Selanjutnya, daya saing ban karet Indonesia di sepuluh negara importir ban karet terbesar di dunia tergolong baik karena sebagian besar nilai RSCA ban karet Indonesia telah bernilai positif selama 2001-2018, kecuali di Prancis yang masih buruk karena cenderung bernilai negatif. Selain itu, Indonesia juga menghadapi negara-negara pesaing dengan daya saing yang juga baik hampir di sepuluh negara importir ban karet terbesar di dunia, yaitu Jepang dan Thailand.

Terakhir, PDB riil perkapita dan jumlah penduduk negara tujuan berpengaruh positif signifikan terhadap nilai ekspor ban karet Indonesia, sementara harga ekspor di negara tujuan dan nilai tukar nominal Dolar AS terhadap Rupiah berpengaruh negatif signifikan terhadap nilai ekspor ban karet Indonesia.

\section{DAFTAR PUSTAKA}

Anne, \& Evan, Russ. (2006). The Composition of a Tyre: Typical Components. Banbury: The Waste \& Resources Action Programme.

Anindhita, A.Y. (2016). Dampak Nilai Tukar Terhadap Perdagangan Internasional Sektor Industri Manufaktur Indonesia (Kuartal I:2005-Kuartal IV:2012). Jurnal Ekonomi dan Bisnis Airlangga Vol.26.

Anshari, M.F., Khilla, A.E., \& Permata, I.R. (2017). Analisis Pengaruh Inflasi dan Kurs Terhadap Ekspor di Negara ASEAN 5 Periode Tahun 2012-2017. Jurnal Info Artha, 1(2),121-128.

Badan Pusat Statistik. (2015). Korespondensi KBKI dengan KKI 1998/1999 KBLI 2009 HS 2012, Buku 3 Komoditi Barang (Seksi 3). Jakarta: BPS RI.

Badan Pusat Statistik. (2018). Statistik Perdagangan Luar Negeri Indonesia Ekspor 2018, Jilid I. Jakarta: BPS RI.

Daras, Usman, \& Towaha, Juniaty. (Februari 2013). "Keunggulan Karet Alam dibanding Karet Sintetis". Medkom Perkebunan, 1(2). Badan Penelitian Tanaman Industri dan Penyegar.

Food and Agriculture Organization of the United Nations (FAO) https://Data.org/faostat/en/\#data/QC

Gabungan Perusahaan Karet Indonesia (Gapkindo). https://www.gapkindo.org/id/statistics/

IndexMundi. https://indexmundi.com/commodities/?commodity=rubber

Indonesian Trade Promotion Center (ITPC)-Mexico City. (2015). Market Brief ITPC-Mexico City 2015, Ban HS Code 4011. Jakarta.

Laursen, Keld. (2015). Revealed Comparative Advantage And Alternatives As Measures Of International Specialization. Eurasian Bus Rev 5, 99-115.

Muharami, Ghufrani, \& Novianti, Tanti. (2018). Analisis Kinerja Ekspor Komoditi Karet Indonesia ke Amerika Latin. Jurnal Agribisnis Indonesia, 6(1), 15-26. 
Saleh, Samsubar, \& Widodo, Tri. (2010). Trade Specialization Indices: Two Competing Models. Journal of Indonesian Economy and Business, 25(2), 129-142.

Tambunan, Tulus. (2004). Globalisasi dan Perdagangan Internasional. Bogor: Ghalia Indonesia.

United Nation Comodity Trade (UN Comtrade) Data. https://comtrade.un.org/data

Wardani, Mia A., \& Mulatsih, Sri. (2017). Analisis Daya Saing dan Faktor-Faktor yang Memengaruhi Ekspor Ban Indonesia ke Kawasan Amerika Latin. Jurnal Ekonomi dan Kebijakan Pembangunan, 6(1), 81-100.

World Bank Data. https://data.worldbank.org 